Diabetologia 11, 89-92 (1975)

(c) by Springer-Verlag 1975

\title{
Gastrin and Insulin Release
}

\author{
J. R. Hayes, J. Ardill and K. D. Buchanan \\ Dept. of Medicine, The Queen's University of Belfast, Northern Ireland
}

Received: April 22, 1974, and in revised form: November 15, 1974

\begin{abstract}
Summary. Gastrin and insulin levels following protein ingestion were measured in control subjects, in patients with vagotomy and pyloroplasty and in patients with vagotomy, antrectomy and gastroenterostomy. Peak gastrin levels preceded peak insulin levels, but no relationship between gastrin output and insulin output was found. The insulin response in patients with impaired gastrin release was similar to that seen in patients with normal gastrin release. Insulin levels
\end{abstract}

after oral glucose in patients with malignant Zollinger-Ellison syndrome were similar to those in patients after gastrectomy, in spite of marked differences in gastrin level. These studies do not suggest that gastrin stimulates insulin release.

Key words: Gastrin, insulin, immunoassay, oral protein, oral glucose, antrectomy, Zollinger-Ellison syndrome.
Oral administration of glucose causes a greater rise in plasma immunoreactive insulin (IRI) concentration than intravenous glucose [1], suggesting that intestinal factors augment the insulin response to the oral stimulus. In man, the intravenous administration of the antral hormone gastrin has been shown both to stimulate insulin release $[2,3]$, and to be without effect [4]. The present investigation used radioimmunoassay techniques to study the effect of endogenous gastrin on insulin release in man.

\section{Material and Methods}

Eight control patients of normal weight and without clinical evidence of diabetes mellitus were studied. After an overnight fast they were given a standard protein meal of cooked minced meat $(25 \mathrm{~g}$ protein in $200 \mathrm{ml}$ ). Peripheral venous samples for hormone assay were taken from a catheter placed in a forearm vein at $0,15,30,45,60,90$ and 120 min after protein ingestion. The plasma was separated and stored at $-20^{\circ} \mathrm{C}$ until assayed. Estimates of the gastrin response were made by measurement of the area under the gastrin curve and above the projected basal [5]. The insulin response was assessed in a similar manner.

Ten patients were studied following surgery for chronic duodenal ulceration. Seven, aged $46 \pm 3$ (mean \pm SEM) years were studied following vagotomy and pyloroplasty and three years aged $42 \pm 7$ (mean \pm SEM), were studied following vagotomy, antrectomy and gastroenterostomy. These patients were given the standard protein meal at least six weeks after surgery.
Three patients (ages 34, 37 and 40) with a malignant Zollinger-Ellison Syndrome were also studied. All had had total gastrectomy. A group of 12 patients with partial gastrectomy for chronic peptic ulceration served as controls. These patients were given $50 \mathrm{~g}$ glucose in $200 \mathrm{ml}$ water, by mouth, after an overnight fast. Peripheral venous samples were taken at 0 , $15,30,60,90$ and $120 \mathrm{~min}$.

Gastrin levels were measured using a sensitive and specific radioimmunoassay [6]. The assay uses antibody raised in rabbits to synthetic human gastrin I [2-17]. The standard used (Human Type Synthetic 68/4399) was obtained from the Medical Research Council. Synthetic human gastrin I was labelled to high specific activity using a modification of the chloramine T method of Hunter and Greenwood [7]. The separation procedure used dextran coated charcoal [8]. The sensitivity of the assay is $10 \mathrm{pg} / \mathrm{ml}$ and cross reactivity with cholecystoskinin/pancreozymin (Mutt) is $1 / 10,000$ on a molar basis. The antibody recognises not only the heptadecapeptide but also 'big' gastrin.

Insulin was measured by a radioimmunoassay using antibody raised against pork insulin. The assay shows identical crossreaction between human insulin (MRC) and pork insulin. A charcoal separation technique was used. The sensitivity of the assay is $1 \mu \mathrm{U} /$ $\mathrm{ml}$.

\section{Results}

The gastrin levels following protein in normal subjects are shown in Table 1 and the insulin levels in Table 2. The peak gastrin level occurred in the 
30 min sample, whereas the peak insulin level was seen at $45 \mathrm{~min}$. There was no correlation between the gastrin response and the insulin response $(r=0.42$ $p>0.1$ ).

The gastrin levels following protein in patients with vagotomy and pyloroplasty and in patients with vagotomy, antrectomy and gastroenterostomy are shown in Fig. 1. The latter procedure markedly reduced basal gastrin level and virtually abolished the
Peak glucose levels in both groups were similar in magnitude and timing suggesting that gastric emptying and glucose absorption in both groups were comparable.

\section{Discussion}

In control subjects (following protein), peak gastrin levels preceded peak insulin levels. It is therefore

Table 1. Gastrin levels following protein in control subjects

\begin{tabular}{|c|c|c|c|c|c|c|c|c|}
\hline & \multicolumn{7}{|c|}{ Gastrin levels (pg/ml) at stated intervals (minutes) } & \multirow{2}{*}{$\begin{array}{l}\text { Gastrin } \\
\text { Response } \\
\text { (arbitrary } \\
\text { units) }\end{array}$} \\
\hline & 0 & 15 & 30 & 45 & 60 & 90 & 120 & \\
\hline E.B. & 70 & 110 & 340 & 160 & 110 & 80 & 90 & 13 \\
\hline J.W. & 60 & 80 & 90 & 160 & 120 & 150 & 140 & 15 \\
\hline K.P. & 100 & 300 & 320 & 300 & 250 & 180 & 100 & 40 \\
\hline R.H. & 100 & 200 & 260 & 190 & 150 & 125 & 140 & 20 \\
\hline D.B. & 80 & 260 & 300 & 250 & 200 & 90 & 50 & 30 \\
\hline G.C. & 75 & 75 & 140 & 90 & 85 & 30 & 60 & 4 \\
\hline F.O. & 50 & 75 & 100 & 120 & 90 & 70 & 60 & 9.5 \\
\hline $\begin{array}{l}\text { T.B. } \\
\text { Mean } \pm\end{array}$ & 50 & 80 & 110 & 110 & 100 & 80 & 70 & 12 \\
\hline SEM & $73 \pm 7$ & $147 \pm 33$ & $207 \pm 38$ & $172 \pm 26$ & $138 \pm 21$ & $100 \pm 17$ & $89 \pm 13$ & \\
\hline
\end{tabular}

Table 2. Insulin levels following protein in control subjects

\begin{tabular}{|c|c|c|c|c|c|c|c|c|}
\hline & \multicolumn{7}{|c|}{ Insulin $(\mu \mathrm{U} / \mathrm{ml})$ at stated intervals (minutes) } & \multirow{2}{*}{$\begin{array}{l}\text { Insulin } \\
\text { response } \\
\text { (arbitrary } \\
\text { units) }\end{array}$} \\
\hline & 0 & 15 & 30 & 45 & 60 & 90 & 120 & \\
\hline E.B. & 9 & 26 & 28 & 63 & 37 & 13 & 1 & 25 \\
\hline J.W. & 7.5 & 9 & 10 & 23 & 15 & 17 & 9 & 9 \\
\hline K.P. & 8.5 & 10 & 16 & 26 & 27 & 20 & 10 & 13.5 \\
\hline R.H. & 2 & 10 & 19 & 28 & 29 & 20 & 18 & 30 \\
\hline D.B. & 16 & 26 & 20 & 16 & 16 & 16 & 27 & 5 \\
\hline G.C. & 8 & 25 & 28 & 34 & 20 & 7 & 8 & 14 \\
\hline F.O. & 11 & 32 & 29 & 39 & 20 & 40 & 40 & 35 \\
\hline T.B. & 9 & 16 & 30 & 32 & 30 & 30 & 25 & 25 \\
\hline Mean \pm & & & & & & & & \\
\hline SE & $9 \pm 1.4$ & $19 \pm 3.2$ & $22 \pm 2.5$ & $33 \pm 5$ & $24 \pm 3$ & $20 \pm 3.5$ & $17 \pm 4.6$ & \\
\hline
\end{tabular}

gastrin response to protein. However the insulin response in both groups was similar (Fig. 2).

The insulin levels following oral glucose in patients with malignant Zollinger-Ellison Syndrome and in control gastrectomy patients are shown in Fig. 3. The insulin response in both groups was similar even though there were marked differences in basal gastrin levels. The mean fasting gastrin level in the control group was $34 \pm 2.7 \mathrm{pg} / \mathrm{ml}$ (mean $\pm \mathrm{SEM}$ ), whereas gastrin levels in the Zollinger-Ellison patients were grossly elevated, being 3000,2500 and $1500 \mathrm{pg} / \mathrm{ml}$. possible that gastrin was responsible for the initiation of insulin release. However we found no correlation between the gastrin and insulin response in individual subjects. Following antrectomy, which removes the major source of gastrin and markedly impairs the gastrin response to protein, the insulin response was similar to that seen in patients with an intact antrum. Furthermore, in patients with a malignant Zollinger Ellison Syndrome, with greatly elevated gastrin levels, the insulin response to oral glucose was similar to that seen in gastrectomized subjects. These results 
suggest that physiological concentrations of gastrin contribute little to the insulin response. Budillon et al. [9], who studied gastrin and insulin release following oral and intraduodenal stimuli, reached similar conclusions. Rehfeld and Stadil [10] have shown that intravenous administration of gastrin will only stimulate insulin release when administered in doses which result in serum gastrin concentrations above the

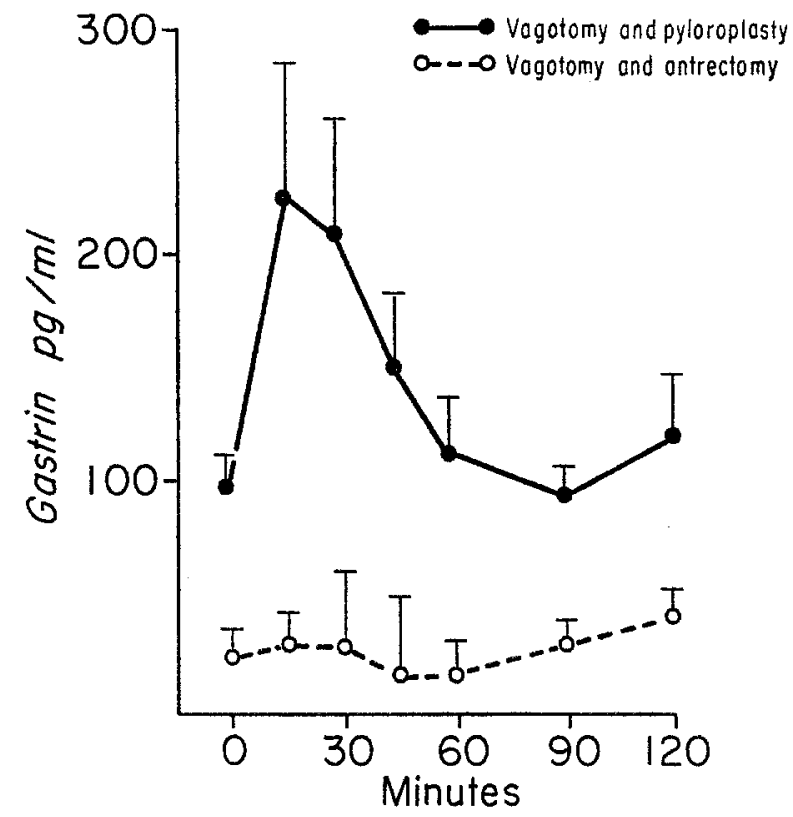

Fig. 1. Gastrin levels following protein in patients with vagotomy and pyloroplasty and in patients with antrectomy and gastroenterostomy (mean \pm SEM)

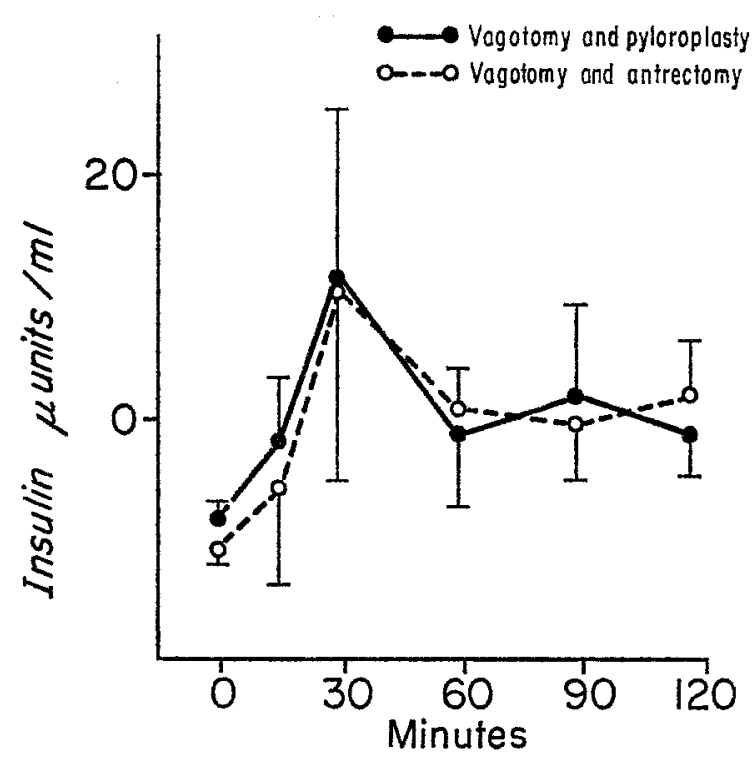

Fig. 2. Insulin levels following protein in patients with vagotomy and pyloroplasty and in patients with antrectomy and gastroenterostomy (mean \pm SEM) physiological range. It is possible that this effect is mediated not by a direct action on the B-cell, but through its effect on other gut hormones or on duodenal $\mathrm{pH}$. That gastrin has no direct effect on the B-cell is suggested by the finding that the hormone does not stimulate insulin release from isolated islets $[11,12]$. With the isolation and identification of new gut hormones, the list of substances possibly respon-

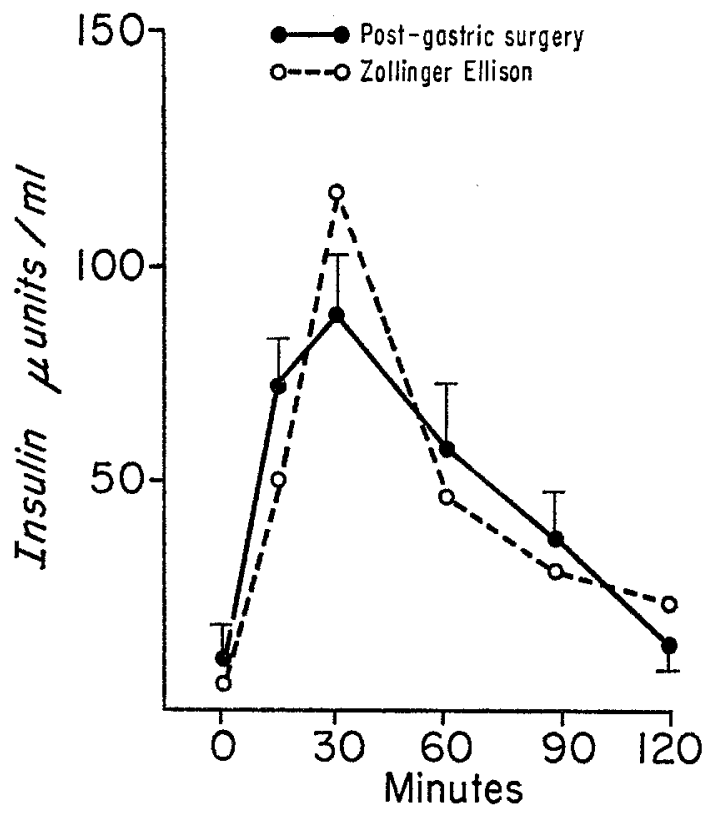

Fig. 3. Insulin levels following oral glucose in patients with malignant Zollinger-Ellison Syndrome and in patients after gastrectomy (mean $\pm \mathrm{SEM}$ )

sible for the greater insulin response to an enterogenous stimulus increases. The problem may only be resolved by the identification of hormone specific receptors on the B-cell membrane.

Acknowledgements. J. R. Hayes was in receipt of a Royal Victoria Hospital Fellowship during the period of these studies. We are grateful for grants from the Northern Ireland Hospitals Authority, G.D. Searle \& Co., and the British Diabetic Association.

\section{References}

1. McIntyre, N., Holdsworth, C. D., Turner, D. S.: New interpretation of oral glucose tolerance. Lancet 1964 II, $20-21$

2. Dupré, J., Curtis, J. D., Waddell, R. W., Beck, J. C.: Effects of secretin, pancreozymin or gastrin on the response of the endocrine pancreas to administration of glucose or arginine in man. J. clin. Invest. 48, 745-757 (1969)

3. Ohgawara, H., Mizuno, Y., Tasaka, Y., Kosaka, K.: Effect of C-terminal tetrapeptide amide of gastrin on insulin secretion in man. J. clin. Endocr. 29, 1261-1262 (1969) 
4. Jarrett, R. J., Cohen, N. M.: Intestinal hormones and plasma insulin: Some observations on glucagon, secretin and gastrin. Lancet 1967 II, 861 -863

5. Berger, S., Downey, J. L., Traisman, H. S., Metz, R.: Mechanism of the cortisone-modified glucose tolerance test. New Engl. J. Med. 274, 1460 - 1464 (1966)

6. Ardill, J.: Radioimmunoassay of gastrin. Phd thesis, The Queen's University of Belfast 1973

7. Hunter, W. M., Greenwood, F. C.: Preparation of Iodine131 labelled human growth hormone of high specific activity. Nature 194, 495-496 (1962)

8. Herbert, V., Lau, K. S., Gottlieb, C. W., Bleicher, S. J.: Coated charcoal immunoassay for insulin. J. clin. Endocr. 25, 1375-1384 (1965)

9. Budillon, G., Mazzacca, G., Squame, G.: Failure of endogenous gastrin release to affect serum insulin. Digestion 8, 201-207 (1973)

10. Rehfeld, J. F., Stadil, F.: The effect of gastrin on basal and glucose stimulated insulin secretion in man. J. clin. Invest. 52, 1415-1426 (1973)

11. Buchanan, K. D., Vance, J. E., Williams, R. H.: Insulin and glucagon release from isolated islets of Langerhans: Effect of enteric factors. Diabetes 18, 381-386 (1969)

12. Hinz, M., Katsilambros, N., Schweitzer, B., Raptis, S., Pfeiffer, E. P.: Role of the exocrine pancreas in the stimulation of insulin secretion by intestinal hormones. The effect of pancreozymin, secretin, gastrin pentapeptide and of glucagon upon insulin secretion on isolated islets of rat pancreas. Diabetologia $7,1-5(1971)$

\section{Dr. R. Hayes}

Division of Endocrinology

Dept. of Medicine

Univ. of Washington

Seattle, Washington 98105

USA

\section{ORGANIZATION SECTION}

\section{Symposium on Cell Membrane Receptors}

The Ninth Miles International Symposium on "Cell Membrane Receptors for Viruses, Antigens and Antibodies, Polypeptide Hormones and Small Molecules" will be held at the Johns Hopkins Medical Institutions, Baltimore, Md., June 4-6, 1975. For further information, contact:

Edward G. Bassett, Ph. D. Symposium Coordinator Miles Laboratories, Inc. Elkhart, IN 46514 U.S.A. (219) 264-8460

\section{9th Congress: International Diabetes Federation New Delhi, India: 31st October - 5th November, 1976}

Suggestions for the programme of this triennial Congress would be welcomed by the Secretary-General: or by any of the Chairmen of the International Advisory Committees, namely: Professor Rolf Luft (European Zone): Professor N. Frienkel (North \& South America): Professor J. Turtle (Australia \& Oceania): Mr. J. G. L. Jackson (Medico-Social programme)

Details from:

\author{
Professor J. S. Bajaj \\ (Secretary-General) \\ 9th IDF Congress Secretariat \\ Post Box 4525 \\ New Delhi 110016 \\ India
}

